九州大学学術情報リポジトリ

Kyushu University Institutional Repository

\title{
First Host Record for Sinauleutes bigibbosus (Hustache) (Coleoptera: Curculionidae: Ceutorhynchinae)
}

Yoshitake, Hiraku

Ito Laboratory, Department of General Systems Studies, Graduate School of Arts and Sciences, The University of Tokyo

Kato, Toshihide

Ito Laboratory, Department of General Systems Studies, Graduate School of Arts and Sciences, The University of Tokyo

Ito, Motomi

Ito Laboratory, Department of General Systems Studies, Graduate School of Arts and Sciences, The University of Tokyo

https://doi.org/10.5109/2864

出版情報: ESAKIA. 46, pp.101-102，2006-06-30. Entomological Laboratory，Faculty of Agriculture, Kyushu University バージョン :

権利関係 : 


\title{
First Host Record for Sinauleutes bigibbosus (Hustache) (Coleoptera: Curculionidae: Ceutorhynchinae)
}

\author{
Hiraku Yoshitake, Toshihide Kato and Motomi Ito \\ Ito Laboratory, Department of General Systems Studies, Graduate School of Arts \\ and Sciences, The University of Tokyo, Tokyo, 153-8902 Japan
}

\begin{abstract}
The host plant of Sinauleutes bigibbosus (Hustache) (Cnemogonini) is reported for the first time. In Japan, this weevil is associated with Hydrangea serrata (Thunb.) Ser. (Saxifragaceae), where it grows in current-year branches during its larval stage.
\end{abstract}

Key words: Coleoptera, Curculionidae, Ceutorhynchinae, Cnemogonini, Sinauleutes bigibbosus, host plant, Hydrangea serrata.

Sinauleutes bigibbosus (Hustache, 1916) is a ceutorhynchine weevil that belongs to the tribe Cnemogonini Colonnelli, 1979 (Alonso-Zarazaga \& Lyal, 1999; Colonnelli, 2004). This species has been reported from Korea and the four main islands of Japan, Hokkaido, Honshu, Shikoku, and Kyushu (Morimoto, 1989; Korotyaev \& Hong, 2004). Although it has been collected on many occasions at least in Japan, no information on its life history has been reported to date.

Through observations from late April to mid-May 2005 on Mt. Takao, Tokyo, Japan, we confirmed that S. bigibbosus is associated with Hydrangea serrata (Thunb.) Ser. (Saxifragaceae). The host plant is a deciduous shrub that constitutes the understory of woodlands and occurs in Honshu, Shikoku, and Kyushu. Hydrangea serrata grew gregariously along a sub-shaded path at the foot of Mt. Takao (Figs. 1, 2), and several adult $S$. bigibbosus were observed feeding on its leaves, creating spotlike feeding traces (Figs. 3, 4). Adult females laid their eggs into current-year branches, and the hatched larvae fed on the soft tissues of the branches (Fig. 5). Under laboratory conditions, full-grown larvae emerged from the branches about two weeks after oviposition. We could not observe the pupal stage, but $S$. bigibbosus may pupate in the soil as do most other ceutorhynchine weevils.

The collection data for specimens examined here are: five males and five females (specimen nos.: HYJPN0000001-0000010), Walkway \#6, Mt. Takao, 35 ${ }^{\circ} 37^{\prime} 50^{\prime \prime} \mathrm{N}, 139^{\circ} 15^{\prime} 43^{\prime \prime E}, 240$ m, Hachiouji, Tokyo, 27
April 2005, T. Kato, on H. serrata; five males and seven females (specimen nos.: HYJPN0000011-0000022), same locality, 12 May 2005, H. Yoshitake, on H. serrata.

All specimens were identified by $\mathrm{H}$. Yoshitake and preserved mostly in his private collection and partly in the Entomological Laboratory of Kyushu University (ELKU). The host plant was identified by M. Ito and the voucher specimen was deposited at the herbarium of the University of Tokyo (TI). Plant nomenclature followed Ohba (2001).

We thank Prof. O. Tadauchi (ELKU) for reviewing this manuscript.

\section{References}

Alonso-Zarazaga, M. A. \& C. H. C. Lyal, 1999. A World Catalogue of Families and Genera of Curculionoidea (Insecta: Coleoptera). (Excepting Scolytidae and Platypodidae). Entomopraxis, Barcelona.

Colonnelli, E., 1979. Note su Panophthalmus e generi affini, con descrizione di una nuova tribù e di una nuova specie della sottofamiglia Ceutorhynchinae (Coleoptera, Curculionidae). Bollettino Ass. Romana Ent., 34: 1-9.

Colonnelli, E., 2004. Catalogue of Ceutorhynchinae of the World, with a Key to Genera (Insecta: Coleoptera: Curculionidae). Argania Editio, Barcelona.

Hustache, A., 1916. Synopsis des Ceuthorrhynchini du Japon. Annls. Soc. Ent. Fr., 85: 107-144.

Korotyaev, B. A. \& K.-J. Hong, 2004. A revised list of the weevil subfamily Ceutorhynchinae (Coleoptera: Curculionidae) of the Korean Fauna, with contribution to the knowledge of the fauna of neighbouring countries. J. Asia-Pacific Entomol., 7 (2): 143-169. 


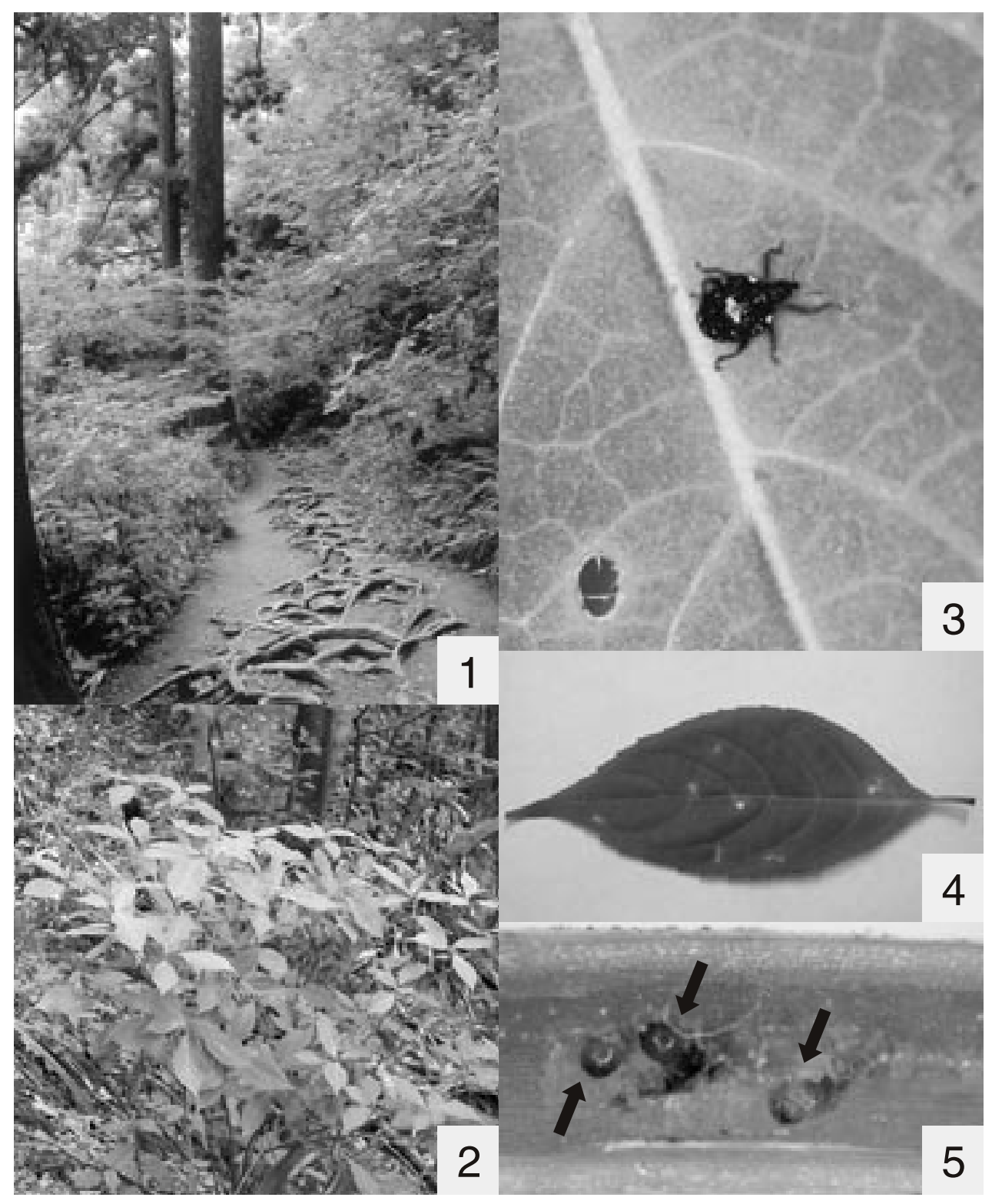

Figs. 1-5. Sinauleutes bigibbosus. 1, Habitat at the foot of Mt. Takao, Tokyo, Japan; 2, the host plant, Hydrangea serrata; 3 , an adult on a leaf of $H$. serrata; 4 , feeding traces of adults on a leaf of $H$. serrata; 5 , three second-instar weevil larvae (indicated by arrows) on a current-year branch of $H$. serrata.

Morimoto, K., 1989. Curculionoidea. In Hirashima, Y. (supervisor), A Checklist of Japanese Insects, 485-538. Entomological Laboratory, Kyushu University, Fukuoka.

Ohba, H., 2001. Hydrangea. In Iwatsuki, K., D. E. Boufford \& H. Ohba (eds.), Flora of Japan IIb, 84-94. Kodansha, Tokyo.

Errata to "Taxonomic Study of the Genus Ceutorhynchoides Colonnelli, 1979 from Japan, with Establishment of an Allied New Genus (Coleoptera: Curculionidae: Ceutorhynchinae)" [ESAKIA, (45): 117-153, March 2005]

On p. 136, l. 1-2: H. monticola sp. nov. should be H. nippon- ensis (Hustache).

On p. 143, 1. 15: Datonychus ?nipponensis should be Datonychus? nipponensis.

On p. 147, 1. 10-13: " 1 male and 2 females, same data as the holotype. Same locality as the holotype (on Symplocos chinensis): 1 male, 19. vi. 2002, Kazuyoshi Izawa; 1 male and 4 females, 2. vii. 2002, H. Yoshitake; 1 male, 29. vi. 2003, Kazuyoshi Izawa." should be "Ohshirakawa, 1250-1340 m, Shirakawa, Gifu (on Symplocos chinensis): 1 male, 19. vi. 2002, Kazuyoshi Izawa; 2 males and 2 females, 28-29. vi. 2002, H. Yoshitake; 1 male and 4 females, 2. vii. 2002, H. Yoshitake; 1 male, 29. vi. 2003, Kazuyoshi Izawa.” 